\title{
Nutritional, Antinutritional Compositions And Organoleptic Analyses Of Raw And Blanched Cocoyam (Colocasia esculenta) Leaves.
}

\author{
${ }^{1}$ Odedeji, J. O., ${ }^{2}$ Oyeleke, G. O., ${ }^{3}$ Ayinde, L. A. and ${ }^{4}$ Azeez, L. A. \\ ${ }^{1}$ Food Technology Department, Osun State Polytechnic, Iree. \\ ${ }^{2}$ Applied Sciences Department, Osun State Polytechnic, Iree. \\ ${ }^{3}$ Mathematics and Statistics, Osun State Polytechnic, Iree. \\ ${ }^{4}$ Food Science and Technology Department, The Polytechnic, Ibadan.
}

\begin{abstract}
This paper highlights the nutritional and antinutritional compositions of raw and blanched cocoyam leaves (Colocasia esculenta). Succulent immature leafy part of cocoyam was harvested in fresh condition from a farmland in Emmanuel College, Samonda, Bodija Area, Ibadan, Oyo State, Nigeria. The leaves were divided into two parts; one was blanched at $80^{\circ} \mathrm{C}$ for 5 mins and the other used on raw basis. Nutritional analysis results reveals that the raw and blanched samples in \% contained 88.5 and 76.9 moisture, 2.7 and 8.4 protein, 0.4 and $0.5 \mathrm{fat}, 2.5$ and 3.1 ash, 2.8 and 2.7 crude fibre, 3.1 and 8.4 carbohydrate, $15(\mathrm{mg} / 100 \mathrm{~g})$ and $8 \mathrm{mg} / 100 \mathrm{~g}$ Vitamin $C$, while the $\beta$ carotene values were $16 \mathrm{mg} / 100$ and $22 \mathrm{mg} / 100$ respectively Antinutritional analysis result revealed that the tannins, phytate and oxalate values $(\mathrm{mg} / \mathrm{kg})$ in raw and blanched leaves were 34.5 and 25.5 , 27.0 and 12.0 and 55.2 and 22.5 respectively. The results revealed that leaves contained appreciable quantity of nutrients, vitamin and low level of antinutrients which was further reduced by blanching. Organoleptic analysis results revealed that there was no significant difference among the sample in term of all the parameters evaluated since F-calculated values were smaller than Q-factor (3.01) at 5\% significant level. This therefore presents the leaves of Colocasia esculenta as a good dietary supplement.
\end{abstract}

\section{Introduction}

Green leafy vegetables are important food item in many Nigerian home. Apart from the variety which they add to the menu, they are valuable sources of nutrients especially in rural areas where they contribute substantially to protein, mineral, vitamins, fiber and other nutrients which are usually in short supply in daily diets [1]. The term vegetable is usually used to desirable soft edible plant product that may be eaten raw or cooked plant product that may be eaten raw or cooked alone or with other preparation. They are seasoned and highly describe owing to their high moisture content, soft and delicate tissues and high rate of physiological activities going on within their cells [2].

Several vegetables species abound in Nigeria which is utilized rather as condiments or spices in human diets or as supplementary feeds to livestock such as rabbits, poultry, swine and cattle [3]. For years, there has been increasing demand for fresh vegetables mainly because of their convenience as ready-to-eat products as well as their health benefits associated with their consumption [4]. Vegetables that is common in Nigeria markets can be categorized into two main categories i.e the common or utilized and the underutilized or miscellaneous categories. The common types include Talinum triangulare (Gbure), Veronia Spp (Ewuro), Amaranthus Spp (Tete), Corchorus oliotorus (Ewedu), Celosia spp (Sokoyokoto), Spinach to mention but few. The under utilized category include: sweet potatoes (lpomea batatas) leaves, and cocoyam (Colocasia esculeutum) leaves. Vegetables serve as an indispensable constituent of the human diet supplying the body with minerals, vitamins and hormone precursors in addition to protein and energy [5]. There abounds in Nigeria many underutilized vegetables whose nutritive and antinutritive compositions and their potentials are yet to be given critical research attention.

Cocoyam, a member of the Araceae family is an ancient crop grown throughout the humid tropics for its edible corns, cormels and leaves, as well as for other traditional uses. The Aracaea family is made up of some hundred genera and more than fifteen hundred species [6]. They are mostly tropical and subtropical. They are cultivated mainly in moist or shady habitats. Some are terrestrial while others are vines, creepers or climbers. Cocoyam is a well known food plant which has a long history of cultivation. Its corns are important source of starch. The corns can be cut up and boiled in curries or fried to make crispy chips. The leaf stalk and matured leaves are also eaten as vegetables.

The malnutrition problems in Nigeria although different in magnitude and severity among different areas are due to protein, vitamins, iron, and other mineral deficiency. This according to Adebooye, [7] calls for 
identifying a broader range of plant species which have potentials as major food sources and for developing these for efficient food production in the Nigerian economy.

This present study therefore has as its objectives the evaluation of nutritional and antinutritional compositions of raw and blanched cocoyam (Colocasia esculenta) leaves with the intention of solving the malnutrition problem both at national and global levels. Equally, organoleptic analysis of soup sample from the leaves in conjunction with three other vegetables was equally investigated.

\section{Materials and Methods}

\subsection{Materials}

The succulent immature leafy parts of the plants of the plant (Colocasia esculenta) were harvested in fresh condition from a farmland in Emmanuel College, Samonda, Bodija Area, Ibadan, Oyo State, Nigeria. The leaves were plucked from the stalk and washed with spray jets of potable water to remove sand and other adhering soil, dirts and contaminants. The leaves were later diced into smaller pieces. The sample was divided into two portions. One part was blanched at $80^{\circ} \mathrm{C}$ for $15 \mathrm{mins}$ and the other was left raw. The two samples were stored for further analyses.

\subsection{Methods}

The proximate analysis of the samples was determined by AOAC [8] method of analysis. The Nitrogen content was estimated by micro Kjeldhal technique and crude protein as $\mathrm{N}$ x 6.25 . Carbohydrate content was determined by difference method. Vitamin $\mathrm{C}$ was determined by the method of AOAC [9]. Oxalate content was by the titrimetric method as modified by Ranjhan and Krishna, [10].

\subsection{Phytate Determination}

$2 \mathrm{~g}$ of each sample was weighed into $250 \mathrm{mls}$ conical flask $100 \mathrm{mls}$ of $2 \%$ concentrated $\mathrm{HCl}$ was used to soak each sample in conical flask for 3 hours. This was filtered through a double major layer of harden filter paper. $50 \mathrm{mls}$ of each filterate was pipetted into $250 \mathrm{ml}$ beaker and $107 \mathrm{mls}$ of distilled water was added in each case. $10 \mathrm{mls}$ of $0.3 \%$ ammonium thiocyanate solution was added into each solution as indicator. This was titrated with standard iron (III) chloride solution which contains $0.000195 \mathrm{~g}$ iron per ml. The end point is slightly brownish yellow which persisted for 5 mins.

\subsection{Organoleptic Analysis}

Soup samples were prepared from cocoyam leaves (Colocacia esculenta) in conjunction with "Soko"Gnetum Africana, "Tete" - Amarantus esculenta and "Gbure" - (Talinum triangulare). These were presented to nine panelists in coded form using multiple comparison method of organoleptic analysis. The panelists evaluated the samples for colour, taste, texture and overall acceptability. The numeric data generated were analyzed using Analysis of Variance (ANOVA) [11].

\begin{tabular}{cl}
\hline SAMPLE CODES & \multicolumn{1}{c}{ DESIGNATIONS } \\
\hline 479 & (Colocacia esculenta) Cocoyam leaves \\
591 & Gnetum africanum (Soko) \\
477 & Amarantus esculenta (Tete) \\
426 & Talium triagulare (Gbure) \\
\hline
\end{tabular}

III. Results And Discussion.

3.1 Results Of Nutritional Analysis Of Raw And Blanched Cocoyam (Colocasia escuenta) Leaves.

The result of nutritional analysis of raw and blanched cocoyam leaves "(Colocasia esculenta) is as presented in table 1.0 below:

\begin{tabular}{|c|c|c|}
\hline PARAMETER & RAW (\%) & BLANCHED (\%) \\
\hline Moisture content & 88.5 & 76.8 \\
\hline Protein & 2.7 & 8.4 \\
\hline Ether extract & 0.4 & 0.5 \\
\hline Ash & 2.5 & 3.1 \\
\hline Crude fibre & 2.8 & 2.7 \\
\hline Carbohydrate & 3.1 & 8.4 \\
\hline Vitamin $\mathrm{C}^{*}$ & 15 & $8 *$ \\
\hline $\begin{array}{l}\beta \text { carotene * } \\
{ }^{*} \mathrm{mg} / 100 \mathrm{~g}\end{array}$ & 16 & $22 *$ \\
\hline
\end{tabular}

From the table the moisture content was found to be $88.5 \%$ and $76.9 \%$ in raw and blanched samples. Vegetables generally are known to have high moisture content and that is why they are susceptible to 
deterioration and spoilage immediately after harvest. The value for the raw (fresh) sample is comparable to $88 \%$ reported for Portulaca quadrifida and lower than 93\% reported for Amaranthus species [12].

The protein content of the raw sample is $2.7 \%$ which falls within the range of values reported for cooked Asystane gangetica (2.8\%) [1]. The protein value increased to $8.4 \%$ after blanching. This might be due to elimination of tannin which is an antinutritional factor by the heat of blanching; this is found to precipitate protein in the raw sample making it unavailable for utilization [13]. The ether extract for the fresh and boiled cocoyam leave samples were found to be $0.4 \%$ and $0.5 \%$ respectively. These values were lower than $5.2 \pm 0.10$ reported for sweet potato leaves [14]. The leaves of cocoyam are therefore not a good source of fat.

The Ash content obtained for fresh sample was $2.5 \%$ and that of blanched sample was $3.1 \%$. These were within the range of Gnectum africana (2.4\% and 3.0\%) and Asystacia gangetica (2.4\% and 3.0\%) reported by Taiwo et al. [1]. The ash content is an index of mineral constituents. High ash content represents higher mineral content. The crude fibre content was found to be $2.8 \%$ for raw and $2.7 \%$ for blanched samples. Blanching therefore has little effect on the sample. The value for the raw sample is comparable to $2.6 \%$ reported for G. pertaphylla and lower than $5.57 \pm 0.01 \%$ reported for Ipomea batatas leaves respectively. The low fibre content of the vegetable could prevent intestinal irritation; improve digestibility and overall increase in nutrient utilization [15].

The carbohydrate content for raw sample was $3.1 \%$ while that of blanched sample was $8.4 \%$. The increase in carbohydrate content after blanching might equally be due to destruction of antinutritional factors binding this nutrient in the raw sample. These values were found to be lower than those reported for some vegetables by [7]. Consumption of leafy vegetable is not for carbohydrate utilization or bioavailability but majorly for protein, minerals and vitamins.

The value recorded for $\beta$-carotene and vitamin $C$ of the raw and blanched samples were $16 \mathrm{mg} / 100 \mathrm{~g}$, $15 \mathrm{mg} / 100 \mathrm{~g}$ and $22 \mathrm{mg} / 100 \mathrm{~g}, 8 \mathrm{mg} / 100 \mathrm{~g}$ respectively. Vitamin $C$ helps prevent scurvy in infant while $\beta$-carotene is Vitamin A precursor which is useful for good sight. Vitamin C content was found to decrease after blanching; this is due to the heat lability of this vitamin.

\subsection{RESULTS OF ANTINUTRITIONAL FACTORS OF RAW AND BLANCHED COCOYAM LEAVES (COLOCASIA ESCULENTA).}

The results of antinutritional factors of raw and blanched cocoyam leaves (Colocasia esculenta) are as presented in Table 2.0 below:

\begin{tabular}{lcr} 
TABLE 2.0:RESULTS OF ANTINUTIRTIONAL FACTORS \\
\hline PARAMETERS & RAW $(\mathrm{mg} / \mathrm{kg})$ & BLANCHED $(\mathrm{mg} / \mathrm{kg})$ \\
\hline Tannins & 34.5 & 25.5 \\
Phytates & 27.0 & 12.0 \\
Oxalates & 55.2 & 22.0
\end{tabular}

From the table, it could be observed that the processing method employed (blanching) had a significant effect on all the antinutritional factors determined. There was drastic reduction in the values of these antinutritional factors between raw and blanched sample. The tannin content for raw sample is $34.5(\mathrm{mg} / \mathrm{kg})$ while that of blanched sample is $25.5(\mathrm{mg} / \mathrm{kg})$. Both values were higher than the $0.22 \pm 0.01 \mathrm{mg} / 100 \mathrm{~g}$ value reported for lpomea batatas leaves [14]. Tannins are phenolic compounds that react with proteins. They are astringent and adversely affect feed intake. Tannins bring about their antinutritional influence largely by precipitation or biding dietary protein and digestive enzymes to form complex, which are not readily digestible [16]. Tannins are known to inhabit the activities of some enzymes like amylase and lipase resulting from the formation of complexes with protein [17]. Processing methods have been shown to reduce the tannin content of food products [18].

The carbohydrate content for raw sample was $3.1 \%$ while that of blanched sample was $8.4 \%$. The increase in carbohydrate content after blanching might equally be due to destruction of antinutritional factor binding this nutrient in the raw sample. These values were found to be lower than those reported for some vegetables by Adebooye, [7]. Consumption of leafy vegetable is not for carbohydrate utilization or bioavailability but majorly for protein, minerals and vitamins.

The phytate content for raw sample is $27.0 \mathrm{mg} / 100 \mathrm{~g}$ while that of blanched sample is $12 \mathrm{mg} / \mathrm{kg}$. These were equally higher than the result obtained for lpomea batatas leaves $(1.42 \pm 0.02 \mathrm{mg} / 100 \mathrm{~g})$ as reported by Oyeleke, [14] and $1.44 \pm 0.1 \mathrm{mg} / 100 \mathrm{~g}$ by Anita et al., [19] for the same leaves. Phytate content of food products has been known to lower the bioavailability of minerals and inhibits the activity of several enzymes [20]. The oxalate content for raw sample is $55.2 \mathrm{mg} / \mathrm{kg}$ and $22 \mathrm{mg} / \mathrm{kg}$ for blanched sample which presents a significant reduction. Heat treatment of vegetable product prior to consumption reduces anti-nutrient generally. 


\subsection{Results Of Orgnoleptic Analysis Of Blanched Cocoyam Leaves In Conjunction With Three Other Vegetables.}

The result of organoleptic analysis of blanched cocoyam leaves in conjunction with Gbure (Talium triagulare), Soko (Colocasia esculentum) and Tete (Amaranthus esculentum) is as presented in Table 3.0 below:

\begin{tabular}{lcc} 
TABLE 3.0-ORGANOLEPTIC ANALYSIS RESULT & \\
\hline PARAMETERS & F-VALUE & Q-FACTOR \\
\hline Color & 0.14 & 3.01 \\
Taste & 0.16 & 3.01 \\
Texture & 1.29 & 3.01 \\
Overall acceptability & 2.79 & 3.01 \\
\hline
\end{tabular}

The F-values obtained for all the samples in all the parameters evaluated were smaller than the Qfactors which showed that there is no significant difference among the samples at $5 \%$ level. However, sample coded 497 (cocoyam leaves received lower rating in term of colour, aroma and even overall acceptability. This might be due to that fact that people are not familiar with the sample compared to others which are mostly consumed by people. Nutritionally, cocoyam leaves (Colocacia esculenta) compete favourable well with the other three samples evaluated together.

\section{Conclusion}

The work revealed that blanched cocoyam leaves present nutrients that can compete with other vegetable normally consumed in Nigeria. The raw sample however contained antinutritional factors which can mask or bind some nutrients making them unavailability. The processing method employed, to a greater extent, reduced these antinutritional factors. This suggests that processing methods can produce nutritionally acceptable product from Colocacia esculenta (cocoyam) leaves. This will increase the utilization of the leaves and improve nutritional intake of people. The organoleptic analysis result revealed that there is no significant difference among the samples in terms of all the parameters evaluated. However, processing methods that will improve the taste and colour of the sample should be encouraged as it received lower rating from panelists.

In view of these, young immature cocoyam leaves have nutritional values which are needed by the body system and can be consumed. Adequate preprocessing methods such as blanching should be employed before consumption.

\section{References}

[1] Taiwo, A.A. Agbotoba, M.O., Oyedepo, J.A., Shobo, A.A, Oluwadara, I. and Olawuro M.O., Effect of Processing on Proximate Composition and Mineral Contents of Selected Indigenous Soup-vegetable of Akwa Ibom State. AJFAND, Vol. 7(2007): 1 - 18.

[2] Odedeji, J.O., E.A., Akande, A.K., Oladele and Adebayo-Oyetaro A.O., Chemical Attributes and Consumer Acceptability of Blends of Fruit Juices from African Star Apple (Chrysophywum albidum) and Mango (Mangifera indica) Journal of Applied Sciences 10(4) (2007): 7353 - 7363.

[3] Aletor V.A and Adeogun, O.A., Nutrient and Antinutrients in Fluted Pumpkin (Telfaira occidentalis) J. Food Chem. 70(1995): 235 -240 .

[4] Doll B., “An Overview of the Epidemiology Evidence Linking Diet and Cancer” Proc Natl Acad. Sci 49(1990) : 119-131.

[5] Oyenuga V.A and Fetuga, B.L., First National Seminar on Fruits and Vegetables. In Proc. Recom \& Papers by NIHORT, Ibadan, Nigeria. (1975): $10-14$.

[6] Okoli, B.E. and Osuji J., An Improved Procedure for Nitotic Study of the Eumusa Section of the Genus Muse L. (Musaleac) Infomusa 5(1)(1996): $1-2$.

[7] Adebooye, O.C., Proximate Composition and Nutrient Analysis of Six Selected Leafy Vegetables of South-West Nigeria. Ife Journal of Agriculture. Vol. 18 (1 \& 2) (1996) $56-63$.

[8] A.O.A.C. Association of Official Analytical Chemists. Official Methods of Analysis. 15 ${ }^{\text {th }}$ Edition. Washington D.C (1990): 90 102 .

[9] A.O.A.C. Association of Official Analytical Chemists. Official Methods of Analysis. 14 ${ }^{\text {th }}$ Edition Washington D.C (1984): 152 164.

[10] Ranjhan, S.R and Krishna, G., In Laboratory Manual of Nutritive Research eds. S.R Ranjhan and G. Krishna Vikas Publishing Company. (1980), New Delhi, India.

[11] Larmond E. (1977). Laboratory Methods of Sensory Evaluation of Foods. Publication Number 1637. Research Branch Department of Agriculture, Ohaw, Canada, (1977): 33 - 57.

[12] Oyeleke, G.O. (2007). Proximate Analysis of Common Vegetables in South-Western Tropics of Nigeria. A Journal of Contemporary Issues in Business and Technology. Vol. (2) No. 4. (2007): $72-79$.

[13] Oboh, G., Tropical Green Leafy Vegetable Garlic Induced Hepatoxicity in the Rat. J. Med. Food. 9(4) (2006):545 - 5521.

[14] Oyeleke, G.O., Nutrient, Antinutrient and Phytochemical Screening of Sweet Potatoes (Ipomea batatas) Leaves. (2006): A Seminar Paper Delivered in the Faculty of Science, Osun State Polytechnic, Iree.

[15] Johns D.F (1987). Factor Influencing Endogenous Amino Acid Secretion. In Proc of the 1987 Symp. Poultry Husbandry. Res. Foundation (1987): $65-80$.

[16] Encarta (R), “(CD) Redmond W.A: Microsoft Corporation, (2006)

[17] Griffith, D.W., The Inhibition of Enzymes by Extracts of Field Beans J. Agric Food Chem. 28 (1979): $459-461$.

[18] Udensi, E.A, and Iwe, M.O., Functional Properties of Pigeon Pea (Cajanus cajan) Predicted Using Response Surface Methodology. Nigeria Food Journal 27(2)(2009): 194 - 203

[19] Anita, B.S, Akpan, E.J and Umoren, I.U., Nutritive and Anti-nutritive Evaluation of Sweet Potatoes (Ipomea batatas) Leaves. Pakistan Journal of Nutrition 5(2), (2006): 166 - 168.

[20] Desphande, S. and Chanyan, M., Changes in Phytic Acid, Tannin and Trypsin Inhibitor Activity on Soaking of Dry Beans (Phaseolus Vulgaris). Nutrition. 27 (1984): 371 - 377. 